\title{
ОРГАНІЗАЦІЯ ПРАКТИЧНОЇ ПІДГОТОВКИ СТУДЕНТІВ-ПРОВІЗОРІВ ПРИ ВИВЧЕННІ ОРГАНІЧНОЇ ХІМІЇ
}

\author{
Г. Я. Загричук, А. Є. Демид \\ ДВНЗ “Тернопільський державний медичний університет \\ імені І. Я. Горбачевського МОЗ України”
}

\section{ARRANGING OF THE PRACTICAL TRAINING IN ORGANIC CHEMISTRY FOR STUDENTS-PHARMACISTS}

\author{
H. Ya. Zahrychuk, A. Ye. Demyd \\ I. Horbachevsky Ternopil State Medical University
}

\begin{abstract}
У статті розглянуто організацію практичної підготовки студентів фармацевтичного факультету в ДВНЗ “Тернопільський державний медичний університет імені І. Я. Горбачевського МОЗ України” при вивченні органічної хімії. Звернуто увагу на формування загальних компетентностей, зокрема: здатності застосовувати практичні знання у критичних ситуаціях, здатності до адаптації та дій у новій ситуації і здатності до абстрактного мислення, здатності проводити дослідження на сучасному науковому рівні, аналізу та синтезу, вчитися й бути сучасно навченим.
\end{abstract}

The article describes how organize practical training in organic chemistry for students of the Pharmaceutical Faculty at SHEI “Ternopil State Medical University by I.Ya. Horbachevsky of MPH of Ukraine”. Attention is paid to the general competencies, including: the ability to apply practical knowledge in critical situations, the ability to adapt and action in the new situation and the capacity for abstract thinking, the ability to conduct research on modern scientific analysis and synthesis, learn and be trained modern.

Вступ. Динаміка розвитку сучасного ринку праці, що обумовлена сучасними процесами в економіці, суттєво вплинула на специфіку вимог, що пред’являються до висококваліфікованих фахівців, в тому числі на фармацевтичному ринку. Працедавці дедалі активніше акцентують свою увагу на здібності провізорів і фармацевтів до практичного рішення завдань, що виникають у процесі професійної діяльності, розвитку не тільки базових знань та умінь, але і загальних компетентностей випускника $[1,2]$. Проте традиційні методи навчання у вищих навчальних закладах (ВН3) не завжди дозволяють сформувати достатній рівень підготовки і випускника ВНЗ, і фахівця.

Тому в університеті важливим фактором підготовки, що сприяє формуванню вміння застосовувати набуті теоретичні знання у практичній діяльності, а відповідно набуттю студентами спеціальних (фахових) компетентностей, є практична підготовка як у процесі навчання, так і на робочому місці [3]. Забезпечити першу частину може правильно організована практична частина заняття, під час якого студенти виконують заплановані дослідження, здійснюють спостереження, узагальнення, висновки

( Г. Я. Загричук, А. Є. Демид
[4]. Практичну підготовку студентів на робочому місці мають забезпечити навчальні та виробничі практики і стажування $[5,6]$.

Метою даної роботи є висвітлення особливостей практичної підготовки студентів-провізорів при вивченні органічної хімії на кафедрі загальної хімії в ДВНЗ “Тернопільський державний медичний університет імені І. Я. Горбачевського МОЗ України”.

Основна частина. Відповідно до типового навчального плану [7] вивчення органічної хімії для студентів спеціальності “Фармація” здійснюється на другому курсі в обсязі 270 год (9 кредитів), у тому числі 30 год лекційних, 116 год практичних занять та 124 год самостійної роботи студентів. Відповідно до робочої програми з органічної хімії передбачено 29 лабораторно-практичних занять, зокрема 14 занять I семестру з тем розділу “Основи будови органічних сполук. Вуглеводні (алкани, циклоалкани, алкени, алкадієни, алкіни, арени) та їх функціональні похідні (галогено-, азотовмісні сполуки, гідроксипохідні вуглеводнів). Альдегіди та кетони” і 15 занять II семестру з тем розділу “Карбонові кислоти, гетероциклічні та природні сполуки”. Органічна хімія відноситься до дисциплін практично-наукової підготовки та є однією із 
дисциплін, засвоєння змісту якої є необхідною для подальшого успішного вивчення професійно-орієнтованих дисциплін: фармацевтичної хімії, фармакогнозії, технології ліків, токсикологічної хімії тощо.

Відповідно до прийнятої структури заняття з органічної хімії проводять у вигляді спарених пар, що дозволяє студентам набути стійких практичних навиків щодо проведення хімічних реакцій, розвитку аналітичного мислення тощо. Методика проведення практичної частини заняття залежно від теми хоча й має певні відмінності, проте основні етапи проведення залишаються практично однаковими:

1. На початку практичної частини заняття здійснюється перевірка виконання домашнього завдання, оформлення практичної роботи, допуск студентів до виконання практичної роботи (перевіряється знання методики виконання реакцій, їх аналітичний ефект, рівняння відповідних реакцій та ін.).

2. Безпосереднє виконання практичної роботи, за яким ретельно слідкує викладач, після завершення якого здійснюється оцінка одержаного результату.

3. Захист практичної роботи, в основі якого лежать пояснення тих аналітичних явищ, що спостерігали студенти, написання рівнянь реакцій, механізмів реакцій тощо.

Враховуючи той факт, що згідно з позиціями європейських випускників та роботодавців одними з найважливіших загальних компетентностей $\epsilon$ інструментальні компетентності, а саме здатність до аналізу та синтезу, розв'язання проблем, здатність до організації та планування, нами на окремих заняттях з органічної хімії заплановано виконання експериментальних задач. Наприклад, при проведенні лабораторно-практичних занять на тему
"Методи встановлення будови органічних молекул. Елементний аналіз: визначення Карбону, Гідрогену, Нітрогену, Сульфуру, галогенів” студенти спочатку виконують типові досліди на виявлення С, $\mathrm{H}, \mathrm{N}, \mathrm{S}$, Hal. Потім вони виконують групові (2-3 студенти) або індивідуальні завдання - одержують невідому речовину (наприклад, саліцилатна кислота, тіосечовина, йодоформ, борна кислота, натрій хлорид, сечовина та ін.). Оскільки в переліку речовин присутні як органічні, так і неорганічні сполуки, студентам необхідно розробити схему аналізу, підтвердити наявність органічних сполук або їх відсутність, а в подальшому доказати наявність у них окремих органогенних елементів. Нами спеціально надаються в переліку сполуки бору, оскільки як при виявленні галогенів пробою Бейльштейна, так і при виявленні сполук Бору передбачається однаковий аналітичний ефект, а це стимулює аналітичне мислення у студентів.

Під час вивчення теми “Визначення фізичних констант органічних сполук (температура кипіння, температура плавлення, показник заломлення)” студенти спочатку знайомляться із методикою проведення визначення відповідних фізичних констант. Після засвоєння методики студенти із визначеного переліку одержують одну або дві невідомі речовини, ідентифікацію яких вони мають провести одним із вивчених методів.

3 метою набуття навичок проведення якісних реакцій для студентів кожного з курсів підготовлено відповідну лінію матрикула практичних навичок, в які з органічної хімії для студентів II курсу включено наступні практичні навички з відповідними рівнями засвоєння [8] (табл. 1).

Таблиця 1. Матрикули практичних навичок для студентів II курсу фармацевтичного факультету з органічної хімії

\begin{tabular}{|c|l|c|c|}
\hline $\begin{array}{c}\text { № } \\
3 / п\end{array}$ & \multicolumn{1}{|c|}{ Назва практичної навички } & $\begin{array}{c}\text { Pівень опа- } \\
\text { нування }\end{array}$ & $\begin{array}{c}\text { Лінія ма- } \\
\text { трикула }\end{array}$ \\
\hline 1 & Виконувати фільтрування при атмосферному та при пониженому тиску & 3 & 2 \\
\hline 2 & Проводити перегонку при атмосферному тиску & 2 & 2 \\
\hline 3 & Проводити якісні реакції на кратний зв’язок, хімізм реакцій & 3 & 2 \\
\hline 4 & $\begin{array}{l}\text { Якісне виявлення елементів С, H, N, O, S, Наl в органічних сполуках, хі- } \\
\text { мізм реакцій }\end{array}$ & 3 & 2 \\
\hline 5 & $\begin{array}{l}\text { Проводити ідентифікацію аміногрупи в аліфатичних та ароматичних амі- } \\
\text { нах, хімізм реакцій }\end{array}$ & 3 & 2 \\
\hline 6 & $\begin{array}{l}\text { Проводити виявлення спиртів та фенолів різної будови серед інших класів } \\
\text { органічних сполук, хімізм реакцій }\end{array}$ & 3 \\
\hline 7 & $\begin{array}{l}\text { Проводити виявлення карбонілвмісних сполук (альдегіди, кетони) серед } \\
\text { інших класів органічних сполук }\end{array}$ & 2 \\
\hline 8 & $\begin{array}{l}\text { Використання йодоформної проби з метою ідентифікації відповідних ор- } \\
\text { ганічних сполук }\end{array}$ & 3 \\
\hline 9 & $\begin{array}{l}\text { Проводити якісну реакцію на функціональні похідні карбонових кислот } \\
\text { (гідроксамова проба) }\end{array}$ & 3 \\
\hline
\end{tabular}


Продовження табл. 1

\begin{tabular}{|c|l|c|c|}
\hline $\begin{array}{c}\text { № } \\
\text { злп }\end{array}$ & \multicolumn{1}{|c|}{ Назва практичної навички } & $\begin{array}{c}\text { Рівень опа- } \\
\text { нування }\end{array}$ & $\begin{array}{c}\text { Лінія ма- } \\
\text { трикула }\end{array}$ \\
\hline 10 & $\begin{array}{l}\text { Проводити ідентифікацію карбонових кислот (форміатна, ацетатна, окса- } \\
\text { латна, бензоатна, саліцилатна, тартратна, лактатна, цитратна) }\end{array}$ & 3 \\
\hline 11 & $\begin{array}{l}\text { Проводити реакції виявлення амінокислот і білків: нінгідринову, біурето- } \\
\text { ву, ксантопротеїнову, цистеїнову }\end{array}$ & 3 & 2 \\
\hline 12 & Проводити ідентифікацію вуглеводів & 3 & 2 \\
\hline 13 & Складати план-схему синтезу органічних сполук згідно з програмою & 1 & 2 \\
\hline
\end{tabular}

Відповідно до організації навчального процесу в університеті [9] складання практичної навички здійснюється студентами під час практичної частини заняття, під час самостійної роботи студентів та в дні відробок чи консультацій, причому рівень оволодіння навичкою повинен бути не нижчий, ніж зазначений у матрикулі щодо кожної навички зокрема. В матрикулі передбачено п’ять рівнів засвоєння.

Перший рівень - це теоретичний виклад усіх етапів її виконання - знає.

Другий рівень передбачає, окрім знання і розуміння усіх етапів виконання практичної навички, хоча б одноразове бачення її виконання на практиці - бачив.

Третій рівень передбачає виконання навички на муляжі, фантомі чи в лабораторних умовах - вміє.

Четвертий рівень вимагає проведення студентом маніпуляції під наглядом викладача - вміє під контролем.

П'ятий рівень виставляється за умови самостійного виконання студентом практичної навички вміє самостійно.

Ще одним етапом розвитку в студентів здатності до аналізу та синтезу, розв’язання проблем, здатності до організації та планування своєї діяльності, а також закріплення здобутих практичних навиків $є$ проведення наприкінці семестру експериментального дослідження.

Викладач видає студенту практичну експериментальну задачу наступного змісту: у семи (або п’яти) пронумерованих пробірках знаходяться водні розчини (або в кристалічному стані) формальдегіду, глюкози, ацетону, молочної кислоти, хлороформу, саліцилової кислоти, ацетооцтового естеру. За допомогою якісних реакцій визначте, в якій пробірці міститься кожна 3 названих речовин. Складіть план-схему визначення, напишіть рівняння відповідних реакцій, вказавши при цьому очікувані аналітичні ефекти.

При проведенні даного визначення не можливо запропонувати систематичний хід аналізу, тому кожен із студентів може запропонувати свій шлях визначення. Для успішного визначення пропону- ється спочатку написати структурні формули запропонованих речовин, визначити в них функціональні групи або фрагменти молекул, наявність яких можна виявити за допомогою відповідних якісних реакцій.

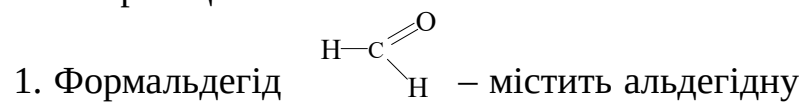
групу, їі визначають за допомогою реакції “срібного дзеркала” або реакції з фуксинсульфітною кислотою тощо.

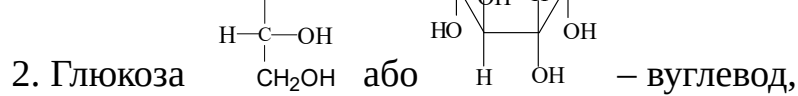
відноситься до моносахаридів, містить альдегідну групу, виявлення якої проводять реакцією “срібного дзеркала”, наявність $\alpha$-діольного фрагмента проводять реакцією з $\mathrm{Cu}(\mathrm{OH}) 2$; також вуглеводи виявляють реакцією Моліша тощо.

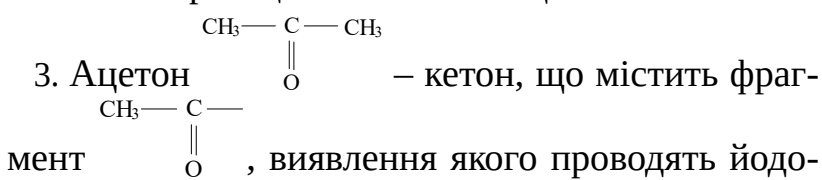
формною пробою, ацетон також виявляють реакцією з натрій нітропрусидом (проба Легаля); наявність кетогрупи можна підтвердити реакцією 3 фенілгідразином чи гідроксиламіном тощо.

4. Молочна кислота $\left.\right|_{\mathrm{OH}} \mathrm{CH}_{-}$ лота, наявність карбоксильної групи можна підтвердити реакцією з $\mathrm{Na}_{2} \mathrm{CO}_{3}$, наявність фрагмента $\mathrm{CH}_{3}-\mathrm{CH}-$

он можна підтвердити йодоформною пробою; при нагріванні молочної кислоти 3 концентрованою $\mathrm{H}_{2} \mathrm{SO}_{4}$ відбувається її розклад за схемою:

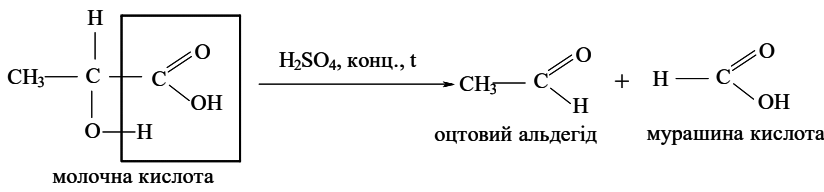




$$
\mathrm{H}-\mathrm{C}_{\mathrm{OH}}^{-\mathrm{O}} \stackrel{\mathrm{H}_{2} \mathrm{SO}_{4} \text {, конц., } \mathrm{t}}{\longrightarrow} \mathrm{CO} \uparrow+\mathrm{H}_{2} \mathrm{O}
$$

При підпалюванні газу, що виділяється, спостерігають блакитне забарвлення полум'я, що свідчить про виділення карбону (II) оксиду. Утворення оцтового альдегіду підтверджують йодоформною пробою - спостерігають випадання жовтого осаду йодоформу з характерним запахом.

5. Хлороформ $\mathrm{CHCl}_{3}$ - містить атом $\mathrm{Cl}$ (галоген), виявлення якого здійснюють пробою Бельштейна, а підтвердження наявності саме атома $\mathrm{Cl}$ - методом Степанова.

6. Саліцилатна кислота $\mathrm{COOH}$ лота; наявність карбоксильної групи можна підтвердити реакцією $3 \mathrm{Na}_{2} \mathrm{CO}_{3}$; наявність фенольного гідроксилу можна підтвердити реакцією $3 \mathrm{FeCl}_{3}$; наявність бензольного кільця, з'єднаного з групою $\mathrm{OH}$ - реакцією $3 \mathrm{Br}_{2}$.
7. Ацетооцтовий естер

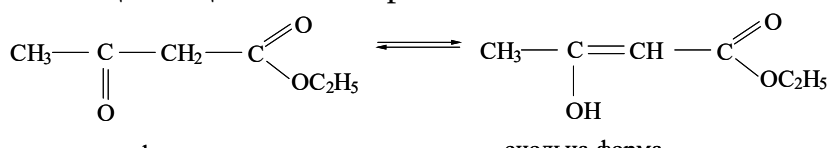

кетонна форма енольна форма

- існує в кетонній та енольній формах. Наявність енольної форми можна підтвердити реакцією 3 $\mathrm{FeCl}_{3}$, наявність подвійного зв'язку - реакцією 3 $\mathrm{Br}_{2}$; наявність естерного угруповання можна доказати гідроксамовою пробою; наявність кетогрупи можна підтвердити реакцією з фенілгідразином або гідроксиламіном, наявність фрагмента $\mathrm{CH}_{3}-\underset{\mathrm{O}}{\mathrm{C}-}$ можна доказати йодоформною пробою.

Після проведення такого детального аналізу стає очевидним, що в деяких випадках з одним і тим же реагентом можуть взаємодіяти декілька речовин. Тому для уникнення двояких трактувань визначення необхідно скласти план-схему аналізу (рис. 1).

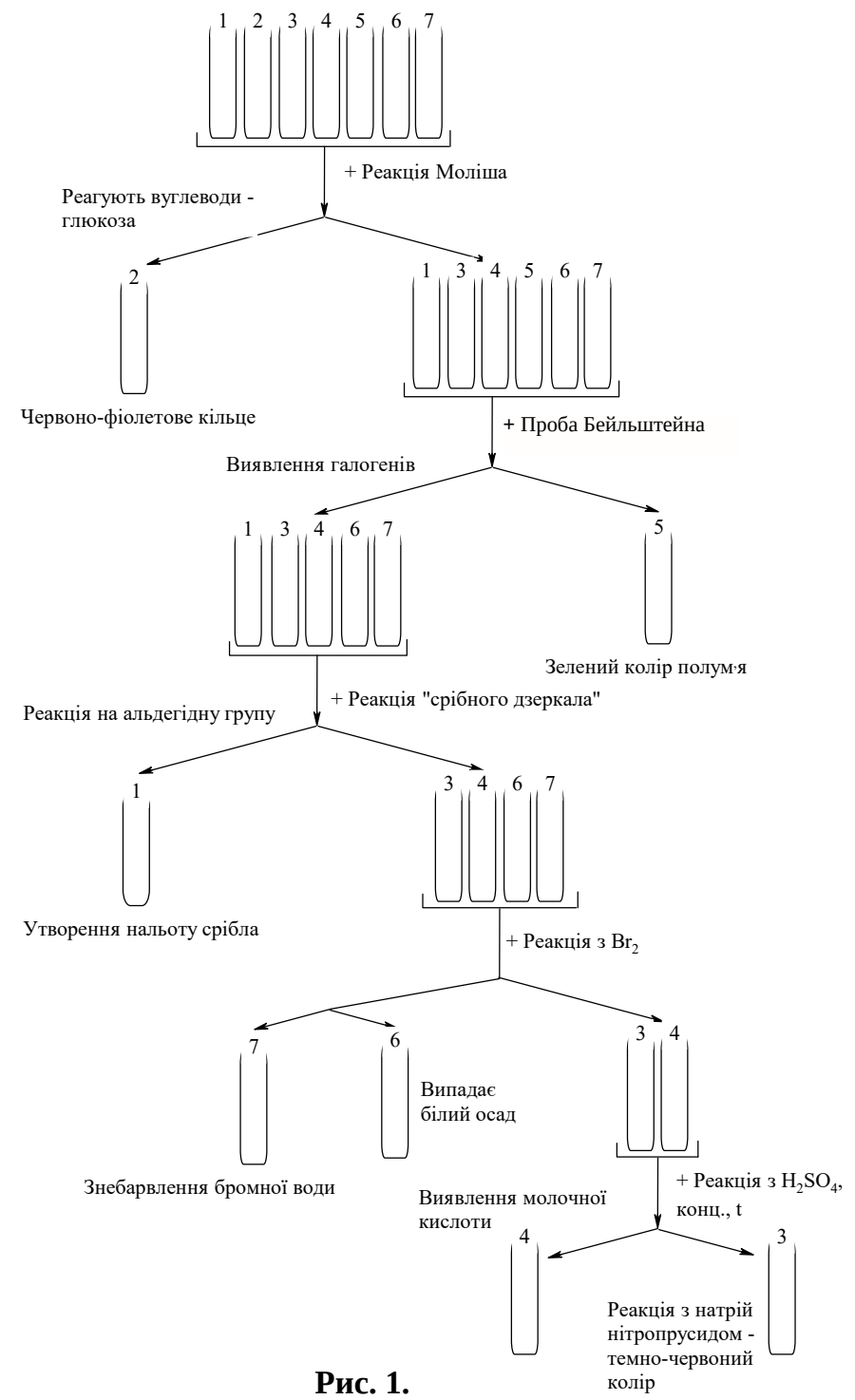


Відповідно до методики проведення дослідження студенти відбирають 3 кожної пробірки невелику порцію речовини і проводять згідно зі схемою певну реакцію до моменту прояву очікуваного аналітичного ефекту.
Для підтвердження виявленої речовини доцільно провести уточнюючу реакцію.

Зовсім іншу схему ми одержуємо, якщо початок визначення розпочати, для прикладу, з йодоформної проби (рис. 2).

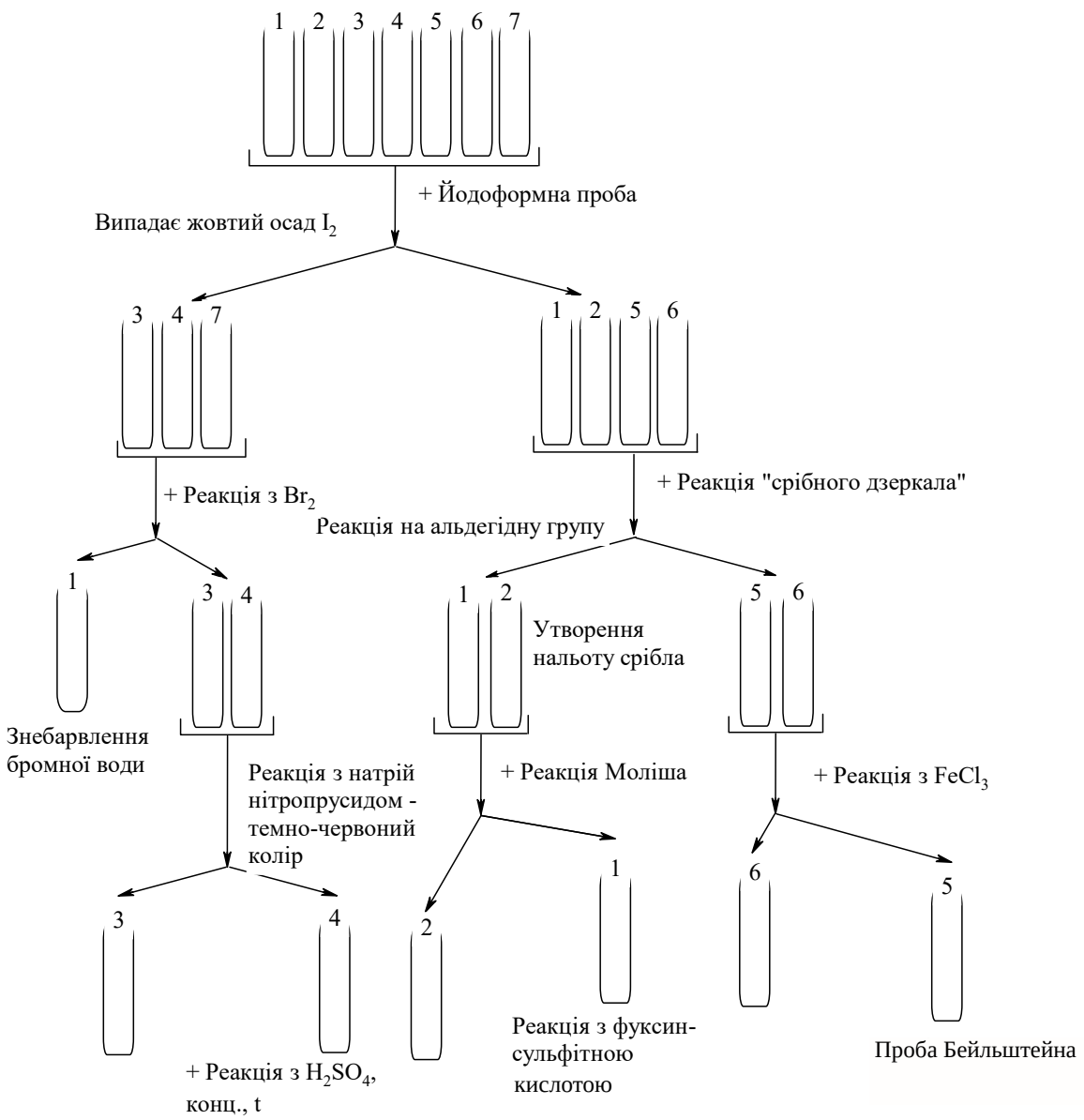

Puc. 2.

Результати проведених досліджень студенти оформляють у вигляді протоколу з вказуванням схеми досліджень, описом методик проведення роботи, рівняннями реакцій і вказуванням розташування досліджуваних речовин у пронумерованих пробірках.

Висновки. Відповідно до правил та вимог належної практики фармацевтичної освіти (Good Pharmacy Education Practice, GPEP) [10] $з$ метою реалізації системи неперервної фармацевтичної освіти (НФО) професійні якості випускника мають включати: надання фармацевтичної допомоги пряма (відпуск ліків тощо) і непряма (технологічні, аналітичні, законодавчі дії і т. д.); управління і керівництво (використання матеріальних і людських ресурсів), навчання (штат, медичні працівники); а також загальні якісні його характеристики: знання, здатність аналізувати ситуацію і приймати рішення, комунікабельність, здатність бути лідером, здатність до вдосконалення власних професійних знань і умінь [11].

Під час вивчення курсу органічної хімії студентам надається можливість не тільки забезпечити майбутніх випускників грунтовними знаннями у галузі природничих, фармацевтичної і медичної наук, які формують необхідний фундамент для фармацевтичної практики в мультипрофесійному середовищі охорони здоров’я, але і розвинути їхні загальні інструментальні компетентності: здатність до аналізу та синтезу, розв’язання проблем, здатність до організації та планування тощо. 


\section{Список літератури}

1. Загричук Г. Я. Підготовка фахівців у вищих навчальних закладах України в сучасних умовах на основі компетентнісного підходу / Г. Я. Загричук, В. П. Марценюк, I. Р. Мисула // Медична освіта. - 2013. - № 1. - С. 8-11.

2. Реалізація міждисциплінарної інтеграції при вивченні хімічних дисциплін студентами фармацевтичного факультету / М. М. Михалків, А. Є. Демид, М. Б. Чубка, І. Б. Івануса // Медична освіта. - 2013. - № 4. - С. 61-65.

3. Досвід запровадження практично-орієнтованого навчання для студентів медичного факультету / I. Р. Мисула, А. Г. Шульгай, Г. Я. Загричук [та ін.] // Медична освіта. - 2009. - № 1. - С. 14-16.

4. Кирилів М. В. Організація навчальної діяльності у формі малих груп при вивченні хімічних дисциплін у вищій школі / М. В. Кирилів, І. Р. Бекус, А. Є. Демид // Медична освіта. - 2013. - № 4. - С. 40-42.
5. http://zakon4.rada.gov.ua/laws/show/z0007-06.

6. Загричук Г. Я. Концептуальні підходи щодо покращення якості підготовки фахівців / Г. Я. Загричук, В. П. Марценюк // Медична освіта. - 2012. - № 4. C. 44-47.

7. http://education.tdmu.edu.ua/roboci-navcalni-plani.

8. http://moodle.tdmu.edu.ua/course/view.phpid=101.

9. http://education.tdmu.edu.ua/about/galuzevi-standartivisoie-osviti.

10. FIP statement of policy on good pharmacy education practice [Electronic resource]. - Approved by FIP Council in Vienna in September 2000. - 8 p. - Access mode: http:// www.fip.org/www/uploads/ database_file.php?id=188).

11. Громовик Б. П. Неперервна фармацевтична освіта в Україні: науково-методичні аспекти управлінськоекономічної підготовки : монографія / Б. П. Громовик, А. В. Горілик. - Львів : РАСТР-7, 2012. - 166 с. 